proportion $(13: 21)$ of atoms to valency electrons. $\mathrm{X}$-rays, aided by electron diffraction, also give information about the crystal texture - the size and arrangement of the crystals as distinct from their inner structure; and the texture is the key to such different problems as the working of metals and the function of biological structures.

\section{The Boulder Dam and its Equipment}

IN Engineering for January $\mathbf{l}$ is a well-illustrated introduction to a series of articles which will deal with the mechanical, hydraulic and electrical features of Boulder Dam. These articles will be written by Mr. P. A. Kinzie, Mr. J. A. Winter and Mr. L. N. McClellan, who have each been responsible for some part of the equipment for the control and utilization of the water impounded by the Boulder Dam, which is not inappropriately described as "the greatest engineering effort of its kind in history". It was on December 21, 1928, that President Coolidge signed the Boulder Dam Act, which provided for the construction of a great dam on the Colorado River. The scheme had several objects. First, it was intended to prevent the serious floods which menaced the fertile district of the Imperial Valley; secondly, to conserve water for use in the same district during the hot dry summers; and thirdly, to provide a public water supply for the coastal cities of Southern California. The river has a length of approximately 1,700 miles, and drains an area slightly more than double the area of Great Britain. The site for the dam was chosen in Black Canyon about 300 miles upstream from the river mouth, a barren and inhospitable region, the character of which is well shown by the photographs in Engineering. The dam itself was completed in the summer of 1935. From the lowest portion of the foundation to roadway level it is 726 feet high; it is 660 feet thick at the base and $45 \mathrm{ft}$. thick at the crest, and contains about $6,600,000$ tons of concrete. It is composed of massive vertical columns about 230 in number, interlocking both vertically and horizontally. Recently, the water impounded in the reservoir, Lake Mead, was estimated at ten billion gallons.

\section{Electric Supply in Palestine}

Av account of electric supply in Palestine since it was initiated in 1923, given in Electrical Industries of December 2, is of special interest in connexion with the political rioting which began last April. The pioneer of this supply was Mr. P. Rutenberg, who enlisted the support of the late Lord Melchett and the Baron E. de Rothschild. It was decided to have a national power supply from water-power, but as the rainfall for Palestine lasts only four months in the year, it was necessary to store the winter rainfall in reservoirs, the construction of which would take several years. It was advisable therefore to use temporary Diesel engine power stations at Haifa and Jaffa to begin the supply, whilst the Dagania dam across the River Jordan and the large one on the Tarmuck River were being constructed. In addition to these dams, Lake Tiberias, which forms a natural reservoir with a surface of 170 million square metres, was utilized. The water-power is converted into electrical power which by highpressure electricity is distributed to Haifa and thence to the north and south of Palestine. In addition, a steam turbine power house was constructed in 1935 and a large power house called the 'Reading' (after the late Marquess of Reading) is being built in southern Palestine.

Wres these plans are completed, the Holy Land will be as highly electrified as any territorial area in the British Empire. During the last three years, the consumption of electricity has quadrupled. There can be little doubt that industrialization is rapidly changing the character of Palestine and that electric power is the main factor in producing this change. Electric lighting, electric power driven machinery and all-mains wireless sets are to be found in small towns, villages and even in remote farming settlements. This is partly due to the fact that the immigrants who come from Germany, America, Czechoslovakia, Austria and the British Dominions, have been accustomed to the use of electric light in factory and home. It looks as if schemes for flooding the Dead Sea from the Mediterranean and so getting electric power possibly for sale to Egypt will soon be considered. One very beneficial effect would be that the constant evaporation from the greatly increased surface of water would humidify the atmosphere and so contribute to the fertility of the region.

\section{Academic Freedom}

THE report of the Conference on Academic Freedom at Oxford in August 1935 and the publication entitled "The Frustration of Science" form the text of a fine plea for academic freedom by M. J. Pelseneer in Revue de l'Universite de Bruxelles of OctoberNovember. M. Pelseneer refers again to the various directions in which academic freedom is threatened and to the necessity for organized united resistance to those threats, and he emphasizes the way in which the freedom of the intellectual is linked up with the freedom of mankind. True liberty of thought is that which liberates mankind from the indignity of bondage. In particular, he pleads for tolerance in the matter of university appointments in the sense not merely of respecting the opinions of others but also in allowing them reasonable opportunity of expression. In this connexion it is interesting to note the conditions in the University of Heidelberg as set out on p. 98 of this issue of Nature. M. Pelseneer, recognizing that human society must look to science for just laws and rational organization, even if their application to the distribution of production and government involves a social revolution, suggests that even within the limits of a given economic system, it is still worth while to discover the means of securing the minimum frustration of science.

\section{Human Welfare and Human Efficiency}

THE relation between industrial and social efficiency, discussed in a leading article in NATURE of October 3 dealing with Sir Josiah Stamp's address to the 
British Association at Blackpool, has been further considered by Mr. W. H Smyth in the Berkeley Daily Gazette of December 5. Mr. Smyth, protesting against the mechanical conception of efficiency, urges that ultimate human efficiency should imply the liberation of man rather than the efficient control of his actions, and that the former as it gains the creative interest of the worker is likely to be the best way of achieving, though indirectly, the latter. He suggests that an act of efficiency which deals with the human element incidentally but with products as its first consideration may inevitably involve disaster to the human element. The art of efficiency in fact is misdirected if it is concerned with production as an end in itself instead of with the development of men possessing vital initiative and creative powers. Mr. Smyth sees the issue as one between human worth and human productive efficiency and one that has a vital bearing on the evolution of alternatives to war. The very value which is now attached to the work of the National Institute of Industrial Psychology in reducing labour turnover, for example, lends powerful support to Mr. Smyth's other pleas that, even in industry, efficiency should be regarded in terms of human welfare as well as of mechanical output and processes.

\section{Citizenship and the Universities}

SHould training for citizenship be an integral part of every undergraduate's curriculum? One of the smaller New England colleges, Hobart, announces a reorganization implying an affirmative answer to this question. Furthermore, the College hopes to make the bachelor's degree "represent less an aggregation of academic achievements and more an integration of intellect and of personality in the primary responsibilities of the citizen towards his community". The announcement is significant, according, as it does, with a growing tendency in the United States to emphasize the universities' obligation to the social order. In his inaugural address, published in School and Society of October 24, the president of the College explains that studies in economics, history, political science and social psychology will in future be so organized as to constitute a progressive four-year course culminating in its final year with a study of contemporary problems in American government and the means of social control. He points out that the 'orientation' courses commonly provided in colleges for the freshman year are well enough for opening the adolescent mind to a glimpse of the problems of the modern world, but are necessarily superficial and elementary compared with what is possible in the fourth year when the student has been equipped with a fairly comprehensive background of knowledge and is ready to envisage political and economic problems with interest as prospective factors in his own life. The dire need of the country for such stiffening as these reforms are calculated to provide is indicated by the statement that "Ballyhoo, the present and audible substitute for rational leadership, is well on the road to becoming the chief creator of American policy and politicians".

\section{The National Botanic Garden of South Africa}

Kinstenbosch, part of the Groot Schuur Estate at Cape Town, South Africa, bequeathed to the nation by Cecil Rhodes, was set apart in 1913 for the purposes of a National Botanic Garden. The report of the Trustees for the year 1936 (issued August 1936) shows that, in spite of its small financial resources, a very gratifying amount of botanical, educational and economic work has been done. The objects of the Gardens are "the collection, cultivation and study of the indigenous flora of South Africa; the preservation of the native vegeta. tion of the areas under control ; and the introduction to cultivation in South Africa of selected economic plants, indigenous and exotic, and their preliminary trial". During the year under review, sixteen new species have been described, and many papers have been published. Large quantities of seeds of various species have been distributed to members of the South African Botanical Society and other institutions and the trade, and more than 200 lots of succulent plants have been propagated. Perhaps the Gardens' most useful activity is shown by the announcement that $1,108 \mathrm{lb}$. of Barosma betulina has been harvested, and also $102 \mathrm{lb}$. of $B$. crenulata, $1 \mathrm{oz}$. of Dalmatian insect powder flowers, $6 \mathrm{lb}$. of sumach, and $3 \mathrm{lb}$. of tansy-products which could be brought within the channels of commerce. Trials of lawn grasses are in progress, and many additions of fresh plants have been made to all parts of the garden. The report shows that the Gardens interpret every aspect of the flora of South Africa in a marked degree. Mr. F. W. Thorns has been appointed curator of the Garden, in succession to Mr. J. W. Mathews, who has held the post of curator since the foundation of the Garden in 1913.

\section{British Empire Cancer Campaign}

Ar the sixty-first quarterly meeting of the Grand Council of the British Empire Cancer Campaign held at 12 Grosvenor Crescent on January 11, the following grants, in addition to those totalling $£ 28,995$ which were made at the annual general meeting in November, have been approved on the recommendation of the Scientific Advisory Committee of the Campaign : $£ 200$ to cover the cost of special physical investigations being carried out under the direction of Dr. F. G. Spear at the Strangeways Research Laboratory, Cambridge ; $£ 500$ for one year to Dr. H. J. Phelps, whilst carrying out experiments in connexion with Dr. Lumsden's anti-cancer serum under the supervision of Dr. Gye and Prof. McIntosh and $£ 440$ for one year to Miss C. F. Fischmann working in the Bernhard Baron Institute of Pathology at the London Hospital.

\section{Tibet Earthquake of January 7}

A GREAT earthquake was recorded in Great Britain at about 1.31 p.m. on January 7. At West Bromwich, as Mr. J. J. Shaw states, the needle of the seismograph was displaced by about $6 \frac{1}{2}$ in., or within half an inch of the amount produced by the Quetta earthquake of 1935. From the records obtained at Kew 